\section{Impaired Biotin Status in Anticonvulsant Therapy}

Klaus-Henning Krause, MD, ${ }^{*}$ Peter Berlit, MD,* and Jean-Pierre Bonjour, PhD†

In 264 epileptics undergoing long-term therapy with anticonvulsants, significantly reduced plasma biotin levels were found compared with a normal control group: $74 \%$ of the epileptics had biotin levels of 250 $\mathrm{ng} / \mathrm{L}$ or less. In patients undergoing single-drug therapy, the mean plasma biotin levels for those treated with sodium valproate were higher than for those treated with phenytoin, primidone, or carbamazepine. The observed reduction in biotin levels might be a factor influencing the efficacy of these three anticonvulsants.

Krause K-H, Berlit P, Bonjour J-P: Impaired biotin status in anticonvulsant therapy. Ann Neurol $12: 485-486,1982$

Recently we reported reduced plasma biotin levels in epileptics undergoing long-term therapy with anticonvulsants [5]. The plasma biotin levels showed a significant negative correlation with the total amount and average daily dose of anticonvulsants administered. Because of the small number of patients examined, no differentiation of the effect of single anticonvulsants could be made. Subsequently, we have investigated 264 patients.

\section{Methods}

Plasma biotin concentrations were determined microbiologically using Lactobacillus plantarum as a test organism, as described by Frigg and Brubacher [4]. The plasma biotin levels of 264 epileptics aged 20 to 40 years were measured. Each had received anticonvulsant therapy for at least one year. At the time of examination 135 patients were taking several anticonvulsants in combination, mostly phenytoin with carbamazepine $(\mathrm{N}=29)$, primidone $(\mathrm{N}=21)$, phenobarbital $(\mathrm{N}=19)$, or a combination of primidone with either sodium valproate $(\mathrm{N}=16$ ) or carbamazepine $(N=13)$. One hundred twenty-nine epileptics were receiving single-drug therapy: 40 with primidone, 31 with phenytoin, 25 with carbamazepine, 12 with sodium valproate, 8 with CHP-phenobarbital, 4 with ethosuxi-

From the *Neurologische Universitätsklinik, Voss-Strasse 2, D6900 Heidelberg, Federal Republic of Germany, and the + Department of Vitamin and Nutrition Research, F. HoffmannLaRoche \& Co, Ltd, CH-4002 Basel, Switzerland.

Received Jan 4, 1982, and in revised form Feb 23. Accepted for publication Mar 12, 1982.

Address reprint requests to Dr Krause. mide, 3 with phenobarbital, 3 with clonazepam, 2 with mesuximide, and 1 with ethadione.

The results of biotin analysis in epileptics were compared with biotin plasma levels for 93 controls (blood donors and patients with dermatological diseases) who had a mean age of 42 years. Statistical analysis between groups was carried out using the Student $t$ test.

\section{Results}

The mean plasma biotin level in epileptics $(227 \pm 80$ $\mathrm{ng} / \mathrm{L})$ was significantly lower $(p<0.0005)$ than that in controls $(448 \pm 201 \mathrm{ng} / \mathrm{L})$. Seventy-four percent of the epileptics had a biotin level of $250 \mathrm{ng} / \mathrm{L}$ or less; only 1 control had a level as low as $250 \mathrm{ng} / \mathrm{L}$ (Figure).

The plasma biotin level (mean \pm SD) in the 135 epileptics undergoing combination therapy was reduced to $231 \pm 76 \mathrm{ng} / \mathrm{L}(p<0.0005$ compared to the controls). The mean plasma biotin levels in patients undergoing single-drug anticonvulsant therapy with phenytoin, primidone, carbamazepine, or sodium valproate are shown in the Table. The epileptics taking sodium valproate had a slightly lower mean plasma biotin level than the controls $(p$ $<0.05$ ) but significantly higher levels than patients treated with other single anticonvulsants (phenytoin, $p<0.01$; carbamazepine, $p<0.01$; primidone, $p<$ 0.001 ). The plasma biotin levels in patients taking these three anticonvulsants were significantly lower than in the controls $(p<0.0005$ in each case).

\section{Discussion}

The previously reported reduction of biotin plasma levels in epileptics undergoing anticonvulsant treatment [5] has been impressively affirmed. Considering that epileptics treated with phenytoin, primidone, or carbamazepine had significantly lower plasma biotin levels than those treated with sodium valproate, the question arises whether the reduction in biotin levels might be a factor in the efficacy of these drugs. A reduction of the biotin-dependent pyruvate carboxylase may cause a reduced level of aspartate via the decrease of oxalacetate. A decline of this neurotransmitter in the brain, caused by phenytoin intake, has recently been demonstrated in animals [6].

Dermatitis and ataxia are clinical manifestations of an inborn error of biotin-dependent enzymes [1-3, $7,8]$. It is of interest that these symptoms are wellknown side effects of anticonvulsants, with the exception of sodium valproate. On the other hand, seizures have been reported in some cases of an inborn error of biotin-dependent enzymes [1, 3, 8]. Altogether, the implication of the reported decline of biotin levels under anticonvulsant treatment is not clear. The pharmacological effect of biotin deficiency in epileptics deserves further attention. 
Plasma Biotin Levels in Epileptics Receiving Single-Drug Therapy

\begin{tabular}{lll}
\hline Anticonvulsant & No. of Patients & Biotin $(\mathrm{ng} / \mathrm{L}$, mean \pm SD) \\
\hline Phenytoin & 31 & $220 \pm 69$ \\
Primidone & 40 & $201 \pm 55$ \\
Carbamazepine & 25 & $218 \pm 59$ \\
Sodium valproate & 12 & $340 \pm 171$ \\
\hline
\end{tabular}

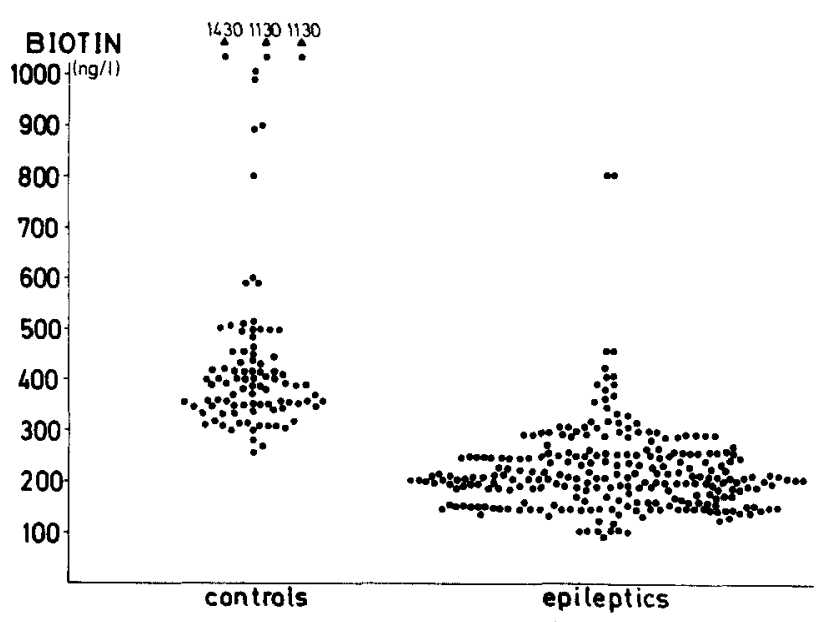

Plasma biotin levels in epileptics receiving long-term anticonvulsant therapy $(N=264)$ and in controls $(N=93)$.

Supported by Grant $\mathrm{Kr}$ 659/1 from the Deutsche Forschungsgemeinschaft.

The authors are indebted to Dr J. P. Vuilleumier, Department of Vitamin and Nutrition Research, F. Hoffmann-LaRoche, for carrying out the biotin determinations.

\section{References}

1. Bonjour J-P: Biotin-dependent enzymes in inborn errors of metabolism in humans. World Rev Nutr Diet 38:1-88, 1981

2. Charles BM, Hosking G, Green A, Pollit R, Bartlett K, Taitz LS: Biotin-responsive alopecia and development regression. Lancet 2:118-120, 1979

3. Cowan MJ, Wara DW, Packman S, Amman AJ, Yoshino M, Sweetman L, Nyhan WL: Multiple biotin-dependent carboxylase deficiencies associated with defects in T-cell and Bcell immunity. Lancet 2:115-118, 1979

4. Frigg M, Brubacher G: Biotin deficiency in chicks fed a wheatbased diet. Int J Vitam Nutr Res 46:314-321, 1976

5. Krause K-H, Berlit P, Bonjour J-P: Erniedrigung des Biotins als möglicher Faktor im Wirkmechanismus von Antiepileptika. Arch Psychiatr Nervenkr 231:141-148, 1982

6. Patsalos PN, Lascelles PT: Changes in regional brain levels of amino acid putative neurotransmitters after prolonged treatment with the anticonvulsant drugs diphenylhydantoin, phenobarbitone, sodium valproate, ethosuximide, and sulthiame in the rat. J Neurochem 36:688-695, 1981

7. Sander JE, Malamud N, Cowan MJ, Packman S, Amman AJ, Wara DW: Intermittent ataxia and immunodeficiency with multiple carboxylase deficiencies: a biotin-responsive disorder. Ann Neurol 8:544-547, 1980

8. Thoene J, Baker $\mathrm{H}$, Yoshino $\mathrm{M}$, Sweetman L: Biotinresponsive carboxylase deficiency associated with subnormal plasma and urinary biotin. N Engl J Med 304:817-820, 1981

\section{Correlation of Isotopic Cisternographic Patterns in Multiple Sclerosis with CSF IgG Values}

S. Bartolini, MD,* D. Inzitari, MD,*

A. Castagnoli, MD, $†$ and L. Amaducci, MD*

Thirty-eight patients with multiple sclerosis (MS) were examined with isotopic cisternography (IC) in order to study cerebrospinal fluid (CSF) dynamics. Cisternography was also performed in 15 patients with amyotrophic lateral sclerosis and in 14 with senile dementia of the Alzheimer type as controls. IC pattern of "mixed" type was found in 18 MS patients and all those with Alzheimer senile dementia examined, while the IC examination did not show abnormality in any of 15 patients with amyotrophic lateral sclerosis. In MS patients, the abnormal IC picture proved to be significantly correlated with the CSF IgG values as calculated by Link's and Tourtelotte's formulas. The abnormal IC in MS may be due to altered CSF reabsorption or increased transependymal flow, or it may be related to the abnormal concentration of IgG.

Bartolini S, Inzitari D, Castagnoli A, Amaducci L: Correlation of isotopic cisternographic patterns in multiple sclerosis with CSF IgG values. Ann Neurol 12:486-489, 1982

In recent years, many investigators have utilized isotope cisternography (IC) to evaluate the formation and absorption of cerebrospinal fluid (CSF) [2-4]. Attempts to correlate the results of isotope tests with various disease states have not always produced consistent associations. Nevertheless, certain patterns have been attributed to the presence of inflammatory

From the *Department of Neurology and the + Nuclear Medicine Service, University of Florence, 50134 Florence, Italy.

Received May 12, 1981, and in revised form Feb 23, 1982. Accepted for publication Mar 15, 1982.

Address reprint requests to Dr Amaducci. 